\title{
Inequality in Indonesia: Kuznets Waves or Kuznets Curve?
}

Dharendra Wardhana ${ }^{1}$

\begin{abstract}
Affiliation
${ }^{1}$ Deputy Director of Social Protection at Directorate of Population Planning and Social Protection, Ministry of National Development Planning/Bappenas
\end{abstract}

Corespondence: dharendra.wardhana@bappenas.go.id

\begin{abstract}
This paper sets out an argument that Kuznets's hypothesis - either Kuznets curve or Kuznets waves - is testable and might only hold depending upon the context. In order to better understand the proposition of Kuznets and its relevance to Indonesia, it is necessary to consider what happens across long periods (la longue durée) and to comprehend how watershed events affect the economy and the distribution of wealth. Analysis in this paper relies on various data sources ranging from conventional economic indicators, historical archives, to literary works. Fluctuation and trends on Gini index in Indonesia might not be fully explained with Kuznets hypothesis although several aspects might influence inequality trends.
\end{abstract}

Keywords: inequality; Kusnetz curve; Kusnetz waves

Doi: https://doi.org/10.47266/bwp.v3i2.67 | page: 168-183

Submitted: June 24 ${ }^{\text {th }} 2020 \mid$ Accepted: August 08 ${ }^{\text {th }} 2020 \mid$ Published: September $07^{\text {th }} 2020$ 


\section{Background}

In view of historical analysis, inequality in Indonesia has been invariably perceived as a consequence rather than a target. Arguably it appears, inequality - as proxied with indicators such as the Gini coefficient or Palma index-is considered amongst one of the most intractable indicators. The main challenge is that inequality can only be controlled only when policy mixture can manage to exert influence towards both lowest and highest income groups.

Before 2015, inequality had been excluded from the national development targets in official planning documents of Government of Indonesia i.e. Medium-Term Development Plan (Rencana Pembangunan Jangka Menengah Nasional or RPJMN) and Annual Government Work Plan (Rencana Kerja Pemerintah or RKP). Instead, the main indicators are largely focused on macroeconomic variables such as economic growth, inflation rate, current account balance, and trade balance. Further, development indicators mentioned in national development plan usually revolve around Human Development Index (HDI), poverty, and unemployment rates. Therefore, prior to 2015 , indicators reflecting redistribution rarely took the attention of policymakers might be simply because they were occupied enough in achieving targets as reflected with several indicators. One factor might point towards topic sensitivity which relates much with issues of appropriateness and legitimacy of one's asset or wealth. Another plausible explanation is due to the limit in formulating intervention to control the variable representing inequality. Unlike poverty or unemployment which both can be addressed through specific programmes, problems and policies pertaining to inequality undeniably involve politics more than any other policies.
Another issue in inequality measurement is on the diverse calculation methods surrounding options of variables on consumption, income, and assets. The debate reached a culmination with Piketty's Capital in the Twenty-First Century (2014), which rattles academic discourse. Reviews and criticisms on Piketty's argument revolved around the significance of inequality and more aggressively on the notion of imposing an inescapable global high tax for the wealthiest group.

Indeed, topics on inequality are heavily contested. The question of inequality and redistribution is central to politics at both local and regional levels. Arguably it seems, ensuing pros and cons arguments seemingly originate from ideological cleavages. The right-wing (usually free-market) position assumes that in the long run, market forces, individual initiatives, and productivity growth are the sole determinants of the income distribution, which implies a reduced role of governments to redistribute wealth. On the other hand, the traditional left-wing position holds that the only way to alleviate the disparity of income is through a social and political struggle, which suggests that the redistributive efforts of government must penetrate to the very heart of the productive process.

Until recently, views on inequality are divided into varying perspectives. At the rightwing position, arguments proposed by Friedman (1962, 1980) and Mankiw (2013) relay similar message and retains the notion that inequality is merely a logical consequence that warrants for less "populist" policies. While at the opposing position, arguments from Stiglitz (2012), Krugman (2014), and Atkinson (2015) mention the urgency to address inequality for its negative impact on economic growth and development.

Friedman (1962:6) mentions three significant reasons in dismissing inequality as 
major problems as follows: (1) Some degree of inequality is desirable in any well-functioning economic system; (2) a certain degree of inequality is unavoidable under an economic system based on free-market principles; and (3) the actual degree of income inequality in observed market economies, such as the United States, is much less than is commonly assumed (especially when compared to income distributions in non-market economies). It is not unpredictable for authors like Friedman, who proposes a laissez-faire approach to correct inequality in the long run.

Meanwhile, Atkinson (2015:23) argues that the rich are getting more productive but also fail to tackle poverty. The economy is rapidly changing to leave most people behind. $\mathrm{He}$ further elaborates that inequality in economic resources translates directly into inequality in personal opportunity. Similarly, Krugman (2014:2) said that inequality is a drag that causes extreme inequality depriving many people of the opportunity to fulfill their potential. Likewise, Stiglitz (2012) puts forward the opinion that inequality is self-perpetuating. Its produced by the vast amount of political power the wealthy hold to control legislative and regulatory activity.

Evidently, both camps can agree upon the consensus that inequality can be regarded as a by-product of development yet its inevitability is highly affected by policies and events. While there are no specific "anti-inequality" policies, redistributive programmes such as land reform, progressive taxation, and targeted cash transfer towards the poor might have the potential to address the problem.

This paper attempts to review recent studies and findings on global inequality and relate to the context of Indonesia. Comparing different historical periods, this study aims to explore any trends, conjectures, patterns and confounding factors explaining inequality. The findings will then be compared with Kuznets proposition.

\section{a. Kuznets curve}

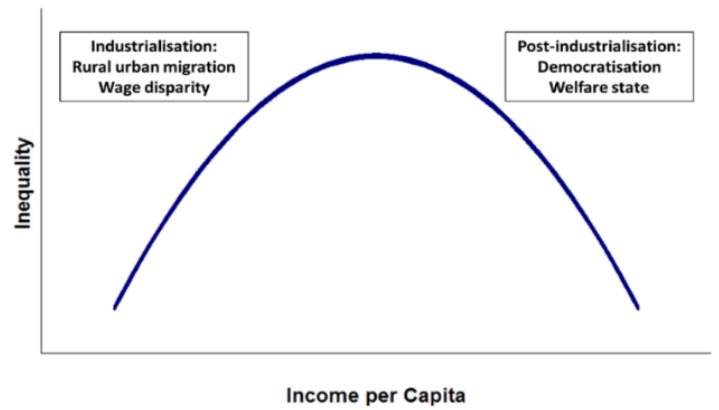

Figure 1. Typical Kuznets Curve

The Kuznets curve implies that as a nation undergoes industrialization-and especially the mechanization of agriculture-the gravity of the nation's economy will shift to the urban areas. This is commonly illustrated with the case of internal migration where farmers looking for better-paying jobs in urban hubs causes a significant rural-urban inequality gap (the owners of firms would be profiting, while laborers from those industries would see their incomes rise at a much slower rate and agricultural workers would possibly see their incomes decrease), rural populations decrease as urban populations increase. As depicted in Figure 1, inequality is then expected to decrease when a certain level of average income is reached ("tipping point") and the processes of industrialization, democratization and the rise of the welfare state allow for the trickle-down of benefits from rapid growth, and finally increase the per-capita income.

Even from its inception in the mid-1950s, the Kuznets curve hypothesis has been one of the most debated issues in development economics. In a nutshell, the hypothesis says that income inequality should usually follow an 
inverse U-shape along the development process. This theory has substantial policy consequences: if least developed countries (LDCs), are not worried about the short-run social costs of development, they should soon reach a situation where growth and inequality reduction converge where poverty rates might drop.

However, as mentioned by Piketty and Saez (2006:3), Kuznets curve in these days is believed to have double back on itself, especially in the US, with the period of falling inequality during the first half of the twentieth century followed by a sharp reversal of the trend since the 1970s. As a consequence, most economists have become relatively skeptical about universal laws relating to development and income inequality. However, with no empirical evidence, it would be misleading to conclude that the Kuznets hypothesis is no longer of interest.

\section{b. Kuznets waves}

Essentially, what the Kuznets waves model does is simply to generalize the insight into the technological revolution, which pushes society to become more and more unequal. Currently, we might be experiencing the $2^{\text {nd }}$ technological revolution with a massive transfer of labor from manufacturing industries to services. Within this notion, the increase in inequality is also driven by technological innovations. Like in Kuznets's time, those who achieved certain technological developments first could gain financial advantage and take home the considerable rent (first-mover advantage). Milanovic (2016:94) argues that now we have a mechanism that is somehow similar to what we had in the past, which, therefore, the second Kuznets waves in the modern era.

At the outset, the form of Kuznets waves finds resemblance with various cycles, ranging from business, economic, and other recurring events. However, no single literature touches upon the possibility of a correlation between Kuznets waves with other cycles/waves. These include Kondratiev wave, Kitchin cycle, Juglar cycle, or Smihul wave, among others.

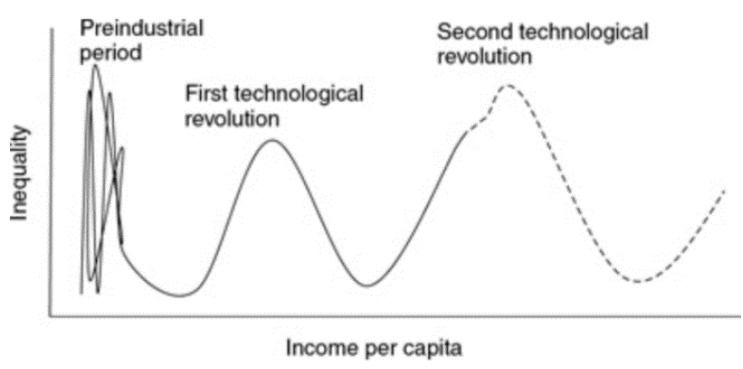

Figure 2. Kuznets Waves (taken from Milanovic, 2016)

Milanovic's second argument is that looking at the developments before the industrial revolution. We find similar waves of inequality; in those days, as the society stagnated, the waves of inequality were not driven by technological changes but by adverse events like outbreaks, disasters, and wars as "the great levelers," according to Scheidel (2017). Therefore, Milanovic (2016:50) argues that there is a secure link between Kuznets and Malthusian cycles in pre-industrial societies. However, Kuznets cycles are broader because demographic changes do not necessarily drive them.

Further, Milanovic elaborates that Kuznets waves in modern societies are visible when plotted against income per capita. The most recent development into account is that inequality mostly driven by technological innovation and structural transformation (two technological revolutions), globalization, politics, and policies (and conflicts). 


\section{c. Global trend of inequality}

As written by Milanovic (2016), global inequality has dramatically changed in the past twenty-five years, which has entangled the political issues either at the between-country level or at the level of the nation-state. Notwithstanding, long term evolution occurs at a within-nation level, and it cycles over the past several centuries.

Income gaps among nations have evolved over the past two centuries. In the 1800 s, only a few countries had achieved economic growth, which consequently translates into the fact that the majority of the population lived in poverty with an income similar to the poorest countries today. Analysis from Roser (2016) shows that at the beginning of the $19^{\text {th }}$ century, the vast majority-cover $80 \%$ - of the world lived in material conditions that are referred to as extreme poverty these days. In the next 175 years, the world dramatically changed to become more un-equal. The world income distribution appeared bimodal with the twohumped shape of a camel. One hump below the international poverty line and a second hump at considerably higher incomes - the world had divided into a poor, developing world and a developed world that was more than 10 - times richer.

Later, in the following four decades, the world income distribution has again changed markedly. The poorer countries, particularly in the South East Asia region, have caught up. Therefore, the two-humped "camel shape" has transformed into a one-humped dromedaryshape. Consequently, distribution has also shifted to the right, which implies that the incomes of many of the world's poorest citizens have increased, and poverty has fallen faster than ever before in human history.

Income distribution has been changing more pro-poor segments, possibly due to globalization and significant political events such as the collapse of the Berlin Wall at the end of the 1990 s and global financial crisis near the end of the 2000s. More importantly, it covers the period that may be called high globalization that catapulted giants like China and probably India to a lesser extent. Deeper integration of emerging economies and communication and technology revolution brought about the unprecedented rate of firms relocating for cheap labor.

Plutocracy and populism affect the global trend of inequality in the $21^{\text {st }}$ century (Freeland, 2012). Wealth concentration tends to build the "new rich on the block," which does not help to alleviate inequality. On the opposing side, a more potent force of populism represented with maneuvers of right-wing activism seems to balance this push. However, most of these acts were simply considered a strategy for large rousing crowds and soliciting votes during political seasons.

\section{Trends and development of inequality in Indonesia}

Historical analysis based on the long-run observation has the potential to provide a more comprehensive and thorough assessment. Perhaps echoing what Rowse (1946) makes a point of the uses of history, its essential value is pointing towards a guide to the possible trend of human affairs. Although most have disagreed with a proverb: " $l$ ' Histoire de répète" (history repeats itself), there must be "rhythms, plots, patterns, even repetitions" (cycles or waves in this regard) which therefore enable us to make generalizations and to draw lessons to a certain degree. This view later carries historical judgment and law rather far, but it is indeed pivotal to drive and shape society's direction.

From the perspective of longue durée, inequality in Indonesia had shown a fluctuating pattern associated with certain significant events. In Indonesia (formerly named as Dutch 
East Indies), the relevant information mainly taken from archives during the colonial period in the $19^{\text {th }}$ century and analyses on these documents. Research from van Zanden (2003:19) shows that high inequality in the fin de siècle period is mainly due to the cleavage in society due to discriminatory policies that were common during the colonial period.

Insights from Leigh and van der Eng (2010:26) suggest that there has not been a sustained long-term increase in income inequality in Indonesia. Interestingly, there was an increase in the top 1 percent income share during the early 1920s and early 1930s, possibly caused by adverse changes in markets for agricultural commodities affecting farm incomes. Meanwhile, in the period 1982-2004, the author found that the top 5 percent income share was lower than in the early-1930s. In short, comparison of top income shares in Indonesia with the available data for other countries shows that the top 1 percent share in Indonesia has been higher than in most countries and years for which comparable data are available.

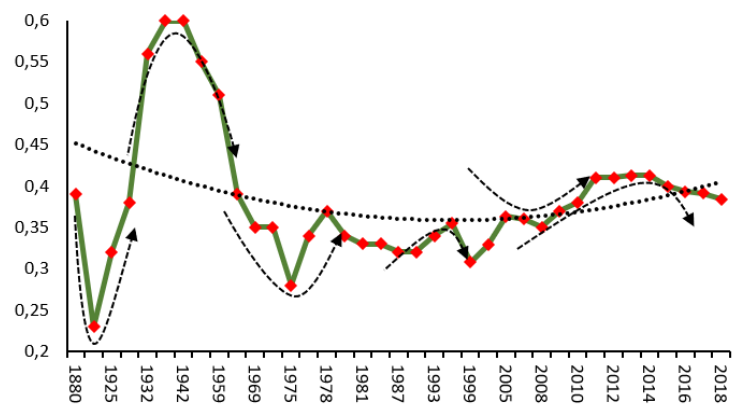

Figure 3. Inequality in Indonesia (1880-2018)

Figure 3 depicts the trajectory of inequality in Indonesia for extended periods using the best available Gini index and its proxies from various sources. There seems a discernible pattern (or waves) in the long curve. Although the curve does not resemble what Kusnetz proposes, the pattern worth examining. At least six visible curves, i.e., three moving upward and other three moving downward curves, could be observed. The longrun trend seems to display a U-shaped curve, although the latest period seemingly indicates a declining rate. The projection for inequality rate is rather tricky than other projections for indicators like GDP, inflation, exchange rates, poverty rates, or unemployment rates. Arguably, there are relatively more confounding variables explaining the degree of inequality and its trends compared to other socio-economic indicators.

\section{a. Inequality in Indonesia during the colonial period}

Figure 3 also depicts sharp fluctuations of inequality in the late $19^{\text {th }}$ century to the mid$2 \mathrm{O}^{\text {th }}$ century. The trend and trajectory of the Gini index in this period show dramatic change regardless of the data reliability. At the outset, this graph conveys a vital message that sharp swing of the Gini index at the early periods seemingly correlates with a high degree of social stratification in the colonial era and uncertainty during revolution time. Meanwhile, in the 1970s onwards, the curve is shown less fluctuation, possibly the impact of development, which oriented towards redistribution. However, the central economic policy is typically purposed to promote economic growth.

At that time, the community divided into racial differences into at least three distinctive classes: indigenous people, merchants from the Arabic peninsula and East Asia regions, and European descents. A novel titled "Max Havelaar" by Multatuli (1868) and Pramoedya Ananta Toer's tetralogy (international reprint edition published in 1991, 1993, 1995, 1996) vividly portrays the striking gaps between the wealthy groups and majority of locals. Both authors intimately acquainted with the hierarchy of status (and wealth) in society during colonial times. They grasped the hidden 
contours of wealth and authority with its necessary implications. Protagonist characters like Nyai Ontosoroh and Minke represent affluent local elite who strongly express and demand for progressive changes.

These novels supposedly agree that a typical feudalistic structure reinforced with a strong tradition of patron-client relationships tends to widen and maintain the gap. Consequently, capitals and assets concentrated under the possession of certain groups like royalties, charitable groups, merchants, and local bureaucrats. On top of that, a highly exploitative policy during British interregnum from 1811 to 1815 and "Cultivation System" (cultuurstelsel), introduced after the extensive Java War (Java Oorlog) in 1830-1850,

In contrast, local peasants and indigenous people (inlander) suffered tremendously, and poverty rates soared high (although the exact figures barely exist due to the lack of data collection). Research notes from Van Hoevell (1849) mention hunger and extreme poverty frequently, as he witnessed in many parts of Java island. He even implies that this suffering is a logical consequence out of cultuurstelsel as echoed by other findings from van Soest (1869), Furnivall (1944), Wertheim (1950), and Boeke (1946).

Meanwhile, in the early years of the $20^{\text {th }}$ century, the Gini index had decreased significantly when the colonial ruler stipulated Ethische Politiek, which marked the start of new development policy encompassing three broad programs: irrigation, migration, and education. Initially designed as policies to compensate previous highly-exploitative policy, Ethical Policy, in no small degree, managed to improve public welfare. This progressive policy - mainly education - in turn, caused the awareness among the middle class and elites and led into rising nationalism sense, which eventually developed into an independent movement and revolutionary struggles.

Although education policy aims to reduce the gap between classes, rising inequality is inevitable, possibly due to the beneficiaries of education programs that mainly focused on specific segments within society. The educated class were mainly coming from families with access or related to colonial governments (“priyayi" class). Lower segments of society might only benefit from irrigation and immigration policies, yet the benefit size might not be as significant as what education program beneficiaries receive.

Counter-intuitively, inequality seemed to increase at the highest level in the last decade of Dutch administration (0.5-0.6). At first, this increasing inequality runs counter to the notion from Scheidel (2017) that inequality will be decreasing along with long-standing conflicts and unstable political situations. However, the trend this decade point towards the declining pattern and the peak of inequality rate was attained in 1939 and 1942, probably when the Ethical Policy showed its impact. Moreover, findings from Leigh and van der Eng (2010) indicate that period of significant economic expansion, primarily based on the growth of commodity export production, might contribute to the increase of inequality to some degree.

\section{b. Inequality in Indonesia during the revolution period}

Gini index remained high until Indonesia's Independence Day. The postrevolutionary era in the 1950s-1960s is characterized by a declining inequality rate, yet it hardly translates into improving public welfare. Although the newly drafted constitution leaned towards socialism principles with bright highlights on redistribution of 
welfare, social welfare problems such as poverty and unemployment persisted.

During this era, policies are primarily driven by leftists and characterized by hostile moves such as nationalization of Dutch companies, "confrontation" policy with Malaysia and Singapore, and massive military expedition following West New Guinea disputes. During this tumultuous period, resources were heavily allocated towards defense spending and mass mobilization, while programs to improve public welfare primarily neglected. The decreasing inequality pattern might follow the conjecture of "asset decompression causes decreasing inequality” assumption. This downward trend stayed until 1975 when the curve began to move upward. Generally, in this period, Indonesia was practically isolated from international trade and multilateral cooperation.

Another exciting novel that is highly relevant to describe the situation in the postcolonial era is "Sang Priyayi" (written by Umar Kayam, 1992). It depicts social stratification intertwines with local values embodied from Javanese aristocratic hierarchy and legacies inherited from contacts with colonial rulers. Background and setting of this novel are in line with findings from Clifford Geertz's ethnographic work titled "Religion of Java" (1960), which emphasizes cleavage among Javanese society. In short, "social climbing" or social mobility is a result of hard work, perseverance, and supports from extended social networks with elites at various levels. Sastrodarsono and Lantrip as main characters are described in this novel as people who can manage to mobilize upward socially and attached to "priyayz" class as well as to its value, commitment, and in-group feeling (Fanani, 2017).

Perhaps as predicted by many, the Sukarno period ended tumultuously with negative economic growth, rampant poverty, hyper-inflation, and other problems occurring out of economic mismanagement. This eventually set the backdrop to power transition in 1966 and elevated Suharto as the new leader who embarked on the different sets of policies focusing on restoring economy and recovering domestic stability.

Observation on Gini index in the period of Sukarno's administration provides cursory glance that inequality seems to be less problematic although in reality the economic situation did not show real improvement. This reinforces the alternative hypothesis that when poverty increases, inequality might decrease but it ends up with "shared poverty". Although shared misery is definitely not a better situation, it somehow creates sense of solidarity and ends up with stability to certain extent. Also, this typical situation correlates with Walter Scheidel's proposition of the assets decompression as a result of adverse events which keeps inequality in check.

\section{c. Inequality in Indonesia during Orde Baru and Reformasi periods}

High economic growth during Orde Baru era was undeniably boosted by the windfall of sky-rocketing world oil prices at the end of 1970 s (Wie, 2012). At that time, Indonesia (along with other OPEC members) was still considered among the largest oil-exporting countries. The benefits were distributed through various programmes in regions mostly in rural areas and agriculture sector. However, the success story-partly built on the importance of economic stability over democracy - had to finish ironically with recurring economic downturn in 1997-98 and finally with political transition towards deepened democratisation.

Apparently, the reformasi momentum in around mid-1998 had uncovered problems and 
triggered initiatives to reform policies. For some observers, the material success of development policies from Orde Baru had actually masked many issues like oppressions, human rights violations, and freedom of speech. These problems were then resolved through constitutional amendments and stipulation of progressive regulations.

Fortunately, recovery process and political reform did not take long. By early 2000 s, Indonesia had managed to devolve much of its responsibilities to local governments while at the same time the country undertook major process of democratisation ultimately implemented with "direct election" mechanism to vote for leaders at the district, municipal, provincial, until country levels. Authoritarian and corrupt system had seemingly been replaced gradually with more democratic and clean institutions. Yet, progress on the economic development had been accompanied with growing trend on inequality which began from 2011 when increasing global price of commodity apparently only benefited few top income groups.

This increasing trend during this period is in line with findings from Yusuf et al (2014). Their estimates suggest that inequality in Indonesia has been rising significantly between 1993 to 2013 . However, the rise in inequality is predominantly visible in the period after the 1997-98 crisis, or during the reformasi era. Before the crisis, inequality rates were relatively stable and moderate (or at least declining slightly).

\section{d. Regional Inequality in Indonesia during Orde Baru and Reformasi periods}

As intuitively as it happens, inequality appears more evident in urban areas-also typical in other developing countries. For the last decade, urban inequality as indicated by Gini index showed increasing trend although in the last few years displayed decreasing trend. On the rural regions, although the inequality had been consistently lower than urban areas, it also showed increasing trend with the last few years stagnated. The fact that urban inequality is higher than rural inequality complies with Kuznets proposition that economic centres and higher wages at urban area naturally attracts labour from rural areas and ultimately increase inequality in urban areas.

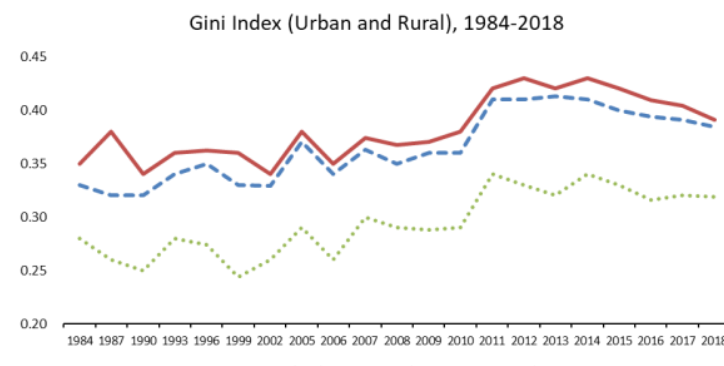
- - National _ Urban ....... Rural

Figure 4. Rural-Urban Inequality in Indonesia

Some hypothesize that the impact of Village Fund (implemented since 2015) had to some extent contributed to if not exacerbated inequality in rural areas, mainly due to the assumption that these disbursed funds had actually benefited only top income layer in society. This assumption is not necessarily untrue as corroborated with findings from Susan and Budirahayu (2017). Their study evaluates the awareness of the law and practice of corruption and development in villages in Indonesia. Even though the village government may know about the law on villages, yet they still do not fully comprehend and practice the principles of good governance particularly on such aspects as transparency, accountability, and information distribution. Most of the village governments do not understand the concept of entitlement and redistribution either. 


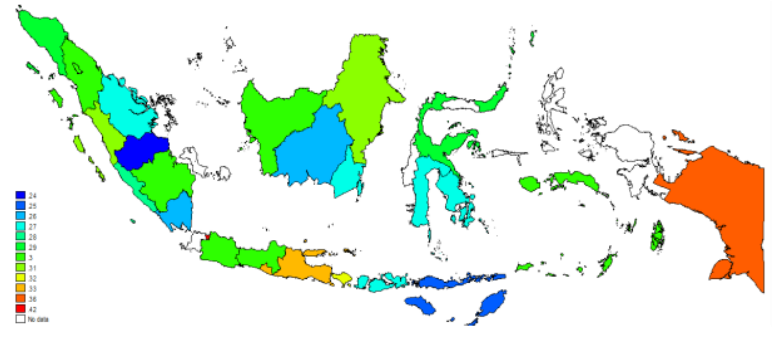

1993

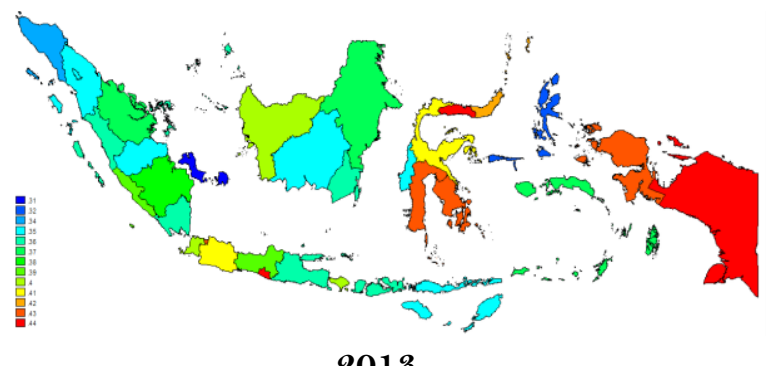

2013

Figure 5. Within-Province Inequality in Indonesia (1993 and 2013)

Figure 5 clearly indicates increasing drift of within-province inequality in the Eastern part of Indonesia (starting from islands of Sulawesi, Maluku, and Papua). In 1993allegedly the peak time of economic success during Orde Baru era-there were only two regions with above-average inequality rates i.e. Jakarta and Papua (at that time there was only one province in Papua island). Meanwhile in 2013, there were at least seven provinces with higher than national average Gini index. Overall, inequality rate at the national level is increasing although there are few provinces indicating lower trend.

This broadened gap at the regional level is probably in line with Kuznets earlier hypothesis that inequality will increase accompanying periods of development. However, in the context of Indonesia and Papua for the specific case, the phenomenon of increasing inequality might correlate with the enactment of Special Autonomy Law. While other regions enjoying "big bang" decentralization, several regions like Yogyakarta and Aceh to large extent receive special additional funding and discretion to retain specific cultures manifested in local regulations.

In 2001, the Indonesian parliament had promulgated the special autonomy legislation for Papua, which was intentionally designed to overcome widespread discontent with central government's rule since the gradual integration of the province had begun in 1962. Many Papuans had suffered under the tight grip of the Orde Baru's militaristic approach and they had witnessed desperately as the area's rich natural resources were extracted largely for the benefit of Jakarta's elite and international investors. With that background, therefore, Indonesia's government and parliament offered to grant Papua the status of a special autonomy province (McGibbon, 2004).

The regulation allows Papua and West Papua provinces to receive significant additional amount of special fund transfers for twenty years. While the original intent of this special autonomy is referring to catch up development progress which had been lagging for decades, the outcome of this special funding does not really translate into expected development.

This case seemingly reflects sub-optimal impact of development spending and the effectiveness of local governance in Papua which cross-cuts with layered and multidimensional problems. While the cause of increasing inequality in Sulawesi might be explained differently and specifically. One possible speculation for the case of Sulawesi is once again referring to Kuznetsian approach which points towards the effect of industrialisation. Unlike other resource-rich provinces which rely heavily on the extractivetype sectors on tradable commodities like coal, palm oil, and minerals, Sulawesi manages to 
enhance values added on manufactured products at certain degree. Therefore, industrialisation in Sulawesi and its corresponding effects might be factors explaining the increasing inequality between 1993 to 2013.

\section{Development of Inequality and} Economy

The first observation to make is that correlation analysis between inequality and income per capita across periods provides important findings (Figure 6). Comparing two different periods characterized by different regimes, policies, and contexts, inequality trends had shown dissimilar patterns at national and at the local levels. At the national level during the period of Orde Baru or commonly abbreviated as "Orba" (analysed periods between 1970 s to late 1990s), the curve resembles near-perfectly U-shape which runs counter with classical Kuznets proposition. While during reformasi period (observed from early 2000 s to date), the curve displays upward swing with a very steep slope. An important message from these curves is clear i.e. that inequality is relatively stable during the Orba era and it jumped high during reformasi period which echoes previous findings from Yusuf et al. (2014).

Gini index was adopted as one of the national targets for the first time in 2015. RPJMN for the years 2015-2019 and annual RKPs within these periods put inequality into attention and the Gini index was clearly mentioned in the document. Table 1 shows targets and realisations for the Gini index as stipulated in RPJMN 2015-2019. From 2015 onwards, deviation from targets had been showing increasing trend from merely two to 20 basis points. This widening differences seemingly conveys the message that inequality is intractable. Put it another way, it might be policies during these periods either did not really effectively address the problem or it might require a long time before the impact kicks in.

Table 1. Targets and Realisations for Gini Index in Indonesia, 2015-2019

\begin{tabular}{cccc}
\hline & $\begin{array}{c}\text { RPJMN } \\
\text { Target }\end{array}$ & Realisation & Difference \\
\hline 2015 & 0.40 & 0.402 & 0.002 \\
2016 & 0.39 & 0.394 & 0.004 \\
2017 & 0.38 & 0.391 & 0.011 \\
2018 & 0.37 & 0.384 & 0.014 \\
2019 & 0.36 & 0.380 & 0.020 \\
\hline
\end{tabular}

Figure 6 depicts the correlation between inequality and economy represented with the Gini index and local GDP per capita, respectively. Correlations at the national and provincial levels are presented in two separate panels. Both graphs display completely different patterns. Overall, inequality is apparently lower during the Orba era at both the national and provincial levels. The main difference can be seen in the era of reformasi (after 1998) where inequality seems higher at both levels but shows different trajectory. At the national level (left-hand side), inequality shows upward trend sharply whereas the graph on the right-hand side shows entirely different pattern. While the overall trend of inequality during the reformasi era is indeed higher than that of the Orde Baru. Short observation indicates both fitted curves seem flat with slight positive slope al though probably in the long run the conjecture might appear to resemble the inverted U-shape-close to the image derived from Kuznets proposition-. A deeper and broader analysis of confounding factors explaining regional variation on inequality is pivotal.

The graph on the left can be associated with remarkable shifts in policy orientation. In the era of Orba, the regime emphasizes 

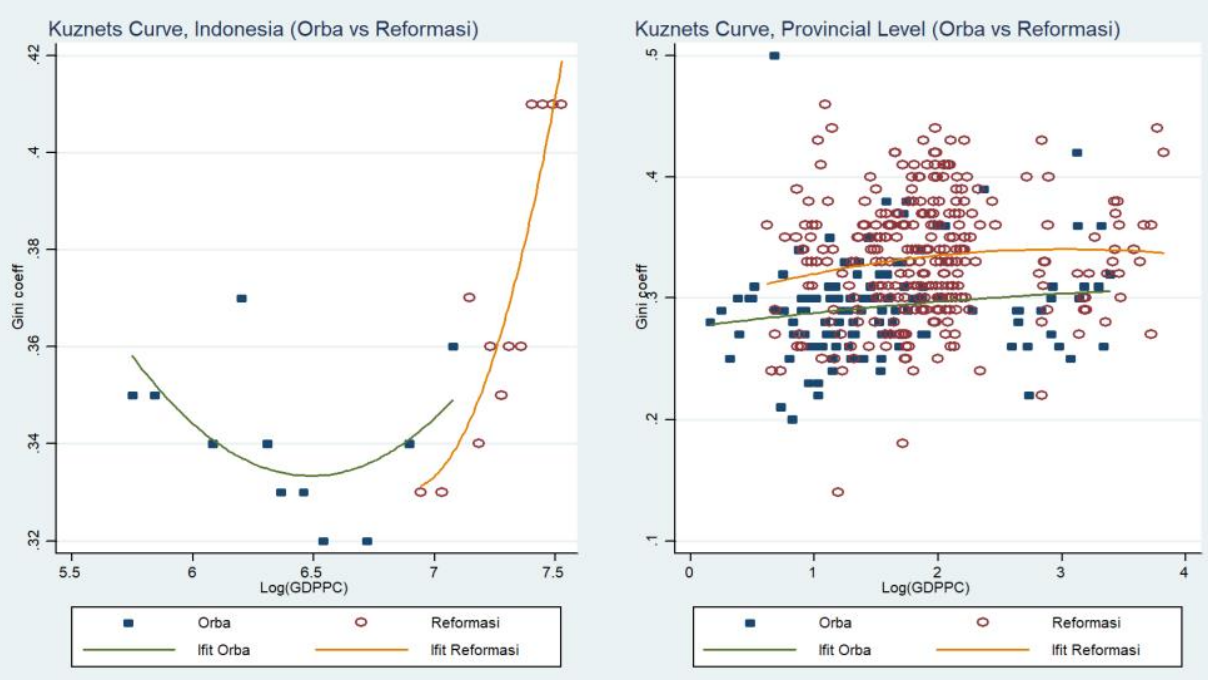

Figure 6. Correlation between Inequality and Economy

redistribution with a focus on agriculture development and industrialization. Later, policy shifts occurred and the accentuation during reformasi period is heavily concentrated on certain economic sectors that benefited a few segments in society. Another factor causing higher inequality is the increasing global commodity price which inevitably only benefits the affluent groups. Furthermore, large scale decentralisation in reformasi period has allowed widening gap between region although findings from Hill and Vidyattama (2014) argue that unlike in other very large developing countries, regional inequality in Indonesia has not risen over the past three decades, reflecting the fact that growth has been reasonably broad-based across regions. Yet they admit that these trends mask considerable diversity. As a matter of fact, Jakarta continues to pull away from the rest of the country, to an extent that could even threaten national cohesion at some point in the future-hence the motivation to relocate the capital city to Kalimantan island. In some respects, Jakarta is becoming 'Bangkok-like' and tend to leave other regions far behind, although Indonesia still has a much more spatially diverse economy than either Thailand or the Philippines.

This important finding on inequality fluctuation leads to several hypothesis related to the proposition of Kuznets waves. However, factors explaining the cycles or the waves might not be identical. Kuznets waves emphasizes on the role of technological revolution and structural transformation while Gini index fluctuation in Indonesia is seemingly more affected by major events resulted from changes on policies and politics.

Economic and social indicators generally move in the same direction, in the sense that richer and faster-growing regions generally have better social indicators. But there are exceptions indeed. The most important is Papua, where the continuing high incidence of poverty clearly demonstrates that the wealth generated in its mining enclaves, and to a lesser extent the major provincial capital of Jayapura, has had limited spill over effects, especially to the more remote and very poor highland region. At the other end of the spectrum, Yogyakarta continues to stand out as having among the best social indicators in the country, even though its 
per capita income is among the lowest, poverty rates have been relatively high, and inequality rates tend to climb in the last decade.

\section{Conclusions}

Indeed, there is still big room for further research on testing Kuznets waves in Indonesia. This paper mainly aims to set out a range of indicative questions. Inequality in Indonesia, while largely and seemingly can be explained with the Kuznetsian approach, is apparently dissimilar from the trajectories of developed countries and probably also from other developing countries. Contrasting the image of the Gini index trajectory for both national and provincial levels leads to the inconclusive argument whether inequality in Indonesia follows either Kusnetz waves or curves. In another perspective, it poses a challenge for future research in order to fill in the gap.

These days, issues revolve around inequality remain unresolved and appear to be increasingly high particularly when using income or assets as proxies. Democratization is assumed to have the capability to affect if not control inequality with the underlying logic that it pushes local leaders for more redistributive programmes encompassing social policies in various forms (cash transfers, health subsidy, education scholarships, micro credits for small-medium enterprises). In fact, this opportunity is not fully realized yet by most local leaders to plan more inclusive policies, especially for vulnerable groups. Rather, most local politics still struggle with issues like money politics (vote buying), patronage, and pragmatic approaches in securing elections (Muhtadi, 2019). With this short-term strategy, politicians tend to appease their constituents through entitlement programmes without careful design. Therefore, its sustainability and its effectiveness are questionable.
Moreover, with this dense political context, most social policies merely focus on the expansion of beneficiaries rather than the quality of its programme. Therefore, it appears that scaling up beneficiaries of social policy is probably directed towards garnering votes instead of welfare improvement. Meanwhile, concerning the current situation, a more radical approach to addressing inequality is urgently needed. Policies such as progressive tax rates, land reform, and other non-conventional instruments like taxation on inheritance, imposing cap ratios on highest-lowest salaries, and universal basic income are indeed worth experimenting with.

As Indonesia is beginning to join the group of upper-middle-income economies, the needs to address wealth disparity among its citizens increasingly becomes more relevant. More importantly, issues on inequality touch upon several contexts. Gaps between urban and rural areas are chief amongst the most popular research on inequality. Another important gap commonly researched is the protracted disparity between regions in Java island and outside Java or regions between Eastern and Western part of Indonesia. Further analysis on the gender disparity also intersects with many issues on inequality at various contexts.

However, it is not implausible to conceive in the long run that inequality will remain one of the most challenging issues. Particularly with the impact of the further technological revolution that is very likely to induce labourreplacing production factors as predicted by Avent (2016) and Schlogl and Sumner (2018). Therefore, the most impending consequences of this future global trend lead to shrinking employment creation and jarring gaps between skilled and unskilled labours. A report from McKinsey (2017) suggests that adaptation to technological change will require higher educational attainment or activities that involve 
social and emotional skills, creativity, high-level cognitive capabilities, and other skills relatively hard to automate.

\section{Post-Script - Curious Case of Yogyakarta: Unequal but Happy?}

For those who are familiar with Indonesia socio-economic indicators will consider the quality of life in Yogyakarta as relatively ideal. Positive progress is reflected with decent indicators on livelihoods such as human development index, longevity, and happiness score among others. Yet, most will be caught surprised knowing that inequality in Yogyakarta is actually the highest in Indonesia from 2017 to 2020. Unfortunately, however, there is a paucity on research explaining this phenomenon. A brief study and short statements from local officials imply that one possible cause determining this highly unequal income distribution is the rapid gentrification of rural areas-most prominently due to the massive development of apartment, shopping malls, and hotels-which leads to dynamic changes of rural-urban status. Villages situated in close proximity with urban areas gradually tend to resemble its characteristics with urban areas although in the official administrative delineation they are still categorized as villages which local officials mention as "urbanvillages". Simply speaking, the category of urban-villages is simply described as a transitory status between urban and rural. Meanwhile rural-villages can be related to the rural areas with lagged development and no significant gentrification. According to local sources, the numbers of "urban-villages" keep increasing and has the proclivity to outnumber "rural-villages" in Yogyakarta.

Within the context of high inequality and the disaster-prone region as a backdrop, Yogyakarta might be susceptible to conflict but on the contrary this province has seemingly been perceived as the safest among other regions in Java. Looking at the aftermath of the massive earthquake in 2006, the community had shown resilience and managed to recover quickly. Perhaps, it is the local social capital and its manifestations which support the society and defuse conflicts during difficult times.

Yogyakarta has been known for a long time as a prime destination for higher education. Top ranked universities such as Gadjah Mada, Atma Jaya, Sanata Dharma, Veteran, Muhammadiyah, Indonesia Islamic University attract potential students from regions all over Indonesia. Probably unlike in the past, most students coming from other regions these days usually are coming from affluent families. Anecdotal evidence seemingly provides a hint of recent trend that most students coming from outside Java have revealed bold preference to stay longer (if not permanently) in Yogyakarta after graduation for working or becoming entrepreneurs. Consequently therefore, new graduates have the proclivity to accumulate wealth and to adjust with modern lifestyle whereas most locals still maintain their modest way of life.

\section{References}

Ananta Toer, P. (1991) This Earth of Mankind (Buru Quartet Book 1). New York: William Morrow \& Co.

Ananta Toer, P. (1993) Child of All Nations (Buru Quartet Book 2). New York: William Morrow \& Co.

Ananta Toer, P. (1995) Footsteps (Buru Quartet Book 3). New York: William Morrow \& Co.

Ananta Toer, P. (1996) House of Glass (Buru Quartet Book 4). New York: William Morrow \& Co.

Atkinson, A. B. (2015) Inequality: What Can Be Done? 1st edn. Cambridge, MA and London, England: Harvard University 
Press.

Avent, R. (2016) The Wealth of Humans: Work, Power, and Status in the Twenty-first Century. New York: St. Martin's Press.

Boeke, J. H. (1946) Oosterse Economie. Den Haag. Bughin, J. et al. (2017) Jobs lost, jobs gained: Workforce transitions in a time of automation. New York. doi: 10.1002/lary.20616.

Fanani, A. (2017) 'Identitas dan mobilitas sosial priyayi dalam novel para priyayi karya umar kayam', Sabda, 12(1), pp. 42-51.

Freeland, C. (2012) Plutocrats: The Rise of the New Global Super-Rich and the Fall of Everyone Else. New York: Penguin Press.

Friedman, M. and Friedman, R. D. (1962) Capitalism and Freedom, Capitalism and Freedom. Chicago: University of Chicago Press.

Friedman, M. and Friedman, R. D. (1980) Free to Choose. New York: Harcourt.

Furnivall, J. S. (1944) Netherlands India: A study of plural economy. New York: The Macmillan Co.

Geertz, C. (1960) The Religion of Java. Chicago and London: University of Chicago Press.

Hill, H. and Vidyattama, Y. (2014) 'Hares and tortoises: regional development dynamics in Indonesia', in Hill, H. (ed.) Regional dynamics in a decentralized Indonesia. Singapore: Institute of Southeast Asian Studies, pp. 68-97.

van Hoevell, W. R. (1849) Reis over Java, Madoera en Bali in het midden van 1847. Amsterdam.

Kayam, U. (1992) Sang Priyayi: Sebuah Novel. Jakarta: Pustaka Utama Grafiti.

Krugman, P. (2014) 'Inequality Is a Drag', The New York Times, 7 August, pp. 18-20.

Leigh, A. and van der Eng, P. (2010) 'Top Incomes in Indonesia, 1920-2004', in Atkinson, A. B. and Piketty, T. (eds) Top
Incomes Over the Twentieth Century: Volume II - A Global Perspective. Oxford and New York: Oxford University Press, pp. 171219.

Mankiw, N. G. (2013) 'Defending the one percent', Journal of Economic Perspectives, 27(3), pp. 21-34. doi: 10.1257/jep.27.3.21.

McGibbon, R. (2004) Secessionist challenges in Aceh and Papua: is special autonomy the solution? 10. Washington DC: East-West Center. Available at: http://scholarspace.manoa.hawaii.edu/b itstream/handle/10125/3510/PSo10.pd f.

Milanovic, B. (2016) Global Inequality: A New Approach for the Age of Globalization. Cambridge, MA and London, England: The Belknap Press of Harvard University Press. doi: 10.1017/CBO9781107415324.004.

Muhtadi, B. (2019) Vote Buying in Indonesia: The Mechanics of Electoral Bribery. Singapore: Palgrave Macmillan. doi: 10.1007/978981-13-6779-3.

Multatuli (1868) Max Havelaar: Or the Coffee Auctions of the Dutch Trading Company. Edinburgh: Edmonston and Douglas.

Piketty, T. and Goldhammer, A. (2014) Capital in the Twenty-First Century. Cambridge, MA and London, England: Belknap Press: An Imprint of Harvard University Press.

Piketty, T. and Saez, E. (2006) The Evolution of Top Incomes: A Historical and International Perspective. 11955. Cambridge, MA. Available at: https://www.nber.org/papers/w 11955.

Roser, M. and Cuaresma, J. C. (2016) 'Why is Income Inequality Increasing in the Developed World?', Review of Income and Wealth, 62(1), pp. 1-27. doi: 10.1111 /roiw. 12153 . 
Rowse, A. L. (1946) The use of history. London: Hodder \& Stoughton.

Scheidel, W. (2017) The Great Leveler: Violence and the History of Inequality from the Stone Age to the Twenty-First Century. Princeton and Oxford: Princeton University Press.

Schlogl, L. and Sumner, A. (2018) The Rise of the Robot Reserve Army: Economic Development, Work, and Wages in Developing Countries. 487. Washington, DC. Available at: https://www.cgdev.org/publication/ris e-robot-reserve-army-automation-andfuture-economic-development-workand-wages.

van Soest, G. H. (1869) Geschiedenis van het Kultuurstelsel. Rotterdam.

Stiglitz, J. E. (2012) The Price of Inequality: How Today's Divided Society Endangers Our Future. New York: W. W. Norton \& Company.

Susan, N. and Budirahayu, T. (2017) 'Village Government Capacity in the Implementation of Village Law No. 6 of 2015 in Indonesia', in McLellan, B. (ed.) Sustainable Future for Human Security: Society, Cities and Governance. Singapore: Springer Nature Singapore Pte Ltd, pp. 17-27. doi: 10.1007/978-981-10-5433-4.

Wertheim, W. F. (1950) Nederlandse cultuurinvloeden in Indonesie.

Wie, T. K. (2012) 'Indonesia's Economic Development During and After the Soeharto Era: Achievements and Failings', in Wie, T. K. (ed.) Indonesia's Economy since Independence. Singapore: ISEAS Publishing, pp. 69-89.

Yusuf, A. A., Sumner, A. and Rum, I. A. (2014) 'Twenty Years of Expenditure Inequality in Indonesia, 1993 - 2013', Bulletin of Indonesian Economic Studies, 50(2), pp. 3741. doi: 10.1080/00074918.2014.939937.

van Zanden, J. L. (2003) 'Rich and poor before the Industrial Revolution: A comparison between Java and the Netherlands at the beginning of the 19th century', Explorations in Economic History, 4O(1), pp. 1-23. doi: 10.1016/SoO144983(02)00028-1. 